\title{
GM FOOD AND COLLECTIVE SIN: \\ A CHRISTIAN THEOLOGICAL ETHICAL REFLECTION ${ }^{1,2}$
}

\author{
Manitza Kotzé \\ University of the Western Cape
}

\begin{abstract}
:
While there are various ethical concerns that are raised in terms of genetically modified (GM) food, there seems to be excellent arguments both for and against most of them. In this article I will argue that ethical concern over the possible destructive socio-economic effects is, however, the area where Christian theological ethics may make the most meaningful contribution. This may also be expressed as the notion of collective sin. An understanding of sin as collective, a mutual situation that we all share and that not only refers to individuals transgressions, but also the very structures and systems that make up our world is particularly helpful in discussing GM food through the lenses of a doctrine of sin. This notion also underlines the socio-economic dangers, where large corporations hold a virtual monopoly over the production and selling of GM food, understanding power as "power over" and domination. The article intends to reflect on this understanding and how it may add value to the larger discussions on the ethical concerns surrounding GM food.
\end{abstract}

Key Words: Bioethics; Doctrine of Sin; Eucharist; Genetic Engineering; GMOs; Power

\section{Introduction}

Food, including what, how, and with whom we eat, occupies a central place in human life and identity. David Freidenreich indicates that food is located at an essential position in human life and accordingly, because of its 'practically infinite diversity' it becomes a powerful mode of expressing and transmitting culture and 'communal identity' (2011:4). Nathan MacDonald further illustrates this connection between food and identity by taking note of national stereotypes. He mentions examples of regional cheeses in France, sausages in Germany and many others (2013:11) to illustrate how food and identity are closely connected.

Denise Ackermann reminds us: "Our bodies are more than skin, bone and flesh. Our bodies encompass the totality of our human experience... Our social reality is an embodied reality" (2006:238). Eating not only sustains our bodies, but also plays a role in comprising

This article was originally a paper presented at the Third Joint Conference of South African Theological Societies on Faith and South African Realities in Pretoria, South Africa, 11-15 July 2016. It was presented at the annual meeting of the Theological Society of Southern Africa (TSSA) on the theme "From Farm to Fork: Theological and Ethical Reflection on the Production, Distribution and Consumption of Food".

2 This research was made possible by the AW Mellon Foundation through the DST/NRF Centre of Excellence in Food Security. 
our embodied reality and our communities; for that reason, eating necessitates not only ethical, but also theological reflection.

Eating is also something that is not simply an individual practice, but usually done communally, as David Brown reminds us: "Eating [has] to be done communally", as it denotes "a world of interdependence, and of individuals as interrelated social beings" (2008).

Brown further argues that before the invention of forks in Western Europe in the fourteenth century, the use of fingers and shared implements meant that table manners affected all those sharing a meal. Communal bonds were therefore "as much lateral as vertical" (2008). Someone such as Erasmus, writing on table etiquette, can accordingly be seen as "continuing a longstanding Christian concern to secure care for the neighbour" (Brown 2008).

With recent publications such as Norman Wirzba's Food and Faith (2011), and Rachel Muers and David Grumett's Eating and Believing (2008), perhaps coupled with a rise in body theology, it has become abundantly clear that food and eating matter; food is more than an article of trade, and eating more than simply the intake of nutrients for sustenance. The acts of producing and consuming food are also spiritual activities that denote our intimate relationship to the rest of creation, non-human and human alike. The consumption of other organisms, even when these organisms are only plants, is by definition a violent system. In addition, as Rian Venter argues in his unpublished Towards an Ethics of Food and Eating, the production of food has also become a violent practice, threatening our bodies and our environment (2011).

One way in which food is produced is through the development and implementation of genetically modified seed. The defence of genetically modified organisms (GMOs) has often been expressed as a form of responsibility to ensure sufficient, nutritious food and keep up with the global demand for more food, while the critique against genetically modified food has portrayed it as an irresponsible overstepping of human boundaries. This contribution will offer an ethical assessment of this argument by investigating the issue of GMOs from the perspective of Christian theology.

The expression 'playing God' is often used by critics to contest the legitimacy of the use of GMO technology, while advocates argue that it would be irresponsible not to use the available technology. In ethical discussion of GMO food, this phrase is also often used, also in secular debates, namely that biotechnology is a means of 'playing God'. Audrey Chapman, writing in Unprecedented Choices: Religious Ethics at the Frontiers of Genetic Science, views the term 'playing God' as a symbolic expression of concern and/or warning over the extensive power of contemporary biotechnology (1999:52). In Cura Vitae: Illness and the healing of life, Daniël Louw, however, indicates that this phrase does not necessarily designate an "objection to manipulating material of life or to resisting contemporary developments in molecular biology and gene technology" (2008:312). For Louw, the statement 'playing God' can also be seen as an expression of wonder and unease, articulating the realisation that humankind is on the brink of understanding the essential machinery of life and how it works (2008:312). In similar vein, the National Council of Churches (USA) document, Genetic Science for Human Benefit states that creation, by divine power, is not static, "but dynamic and ongoing. As creatures uniquely made in God's image and purpose, humans participate in the creative process through the continuing quest for knowledge, which now includes unravelling and learning to control the intricate powers compressed in genes of DNA molecules" (Chapman 1999:44). 
These arguments may well be understood as secularised equivalents of the classic Christian categories of sin as pride and sloth. Advocates of the development and utilisation of biotechnology and GMOs may well appeal to the sin of sloth, arguing that not to use available technology to feed to world would be irresponsible (or even sinful), while those opposed could make the case that the motives behind such action would be hubris, proud $\sin$.

On this basis, this contribution will examine the use of such categories within the context of Christian discourse of $\sin$ with reference to the collective and structural dimensions of the abuse of power, including economic, agricultural and technological power.

\section{Genetically Modified Organisms (GMOs) and Christian Ethics: Arguments for and Against}

Molecular genetics was made possible by the discovery of the existence of genes on chromosomes. The mechanisms of inheritance were further refined, recognising that many inherited traits or characteristics are not the result of single genes, but a specific combination of genes (Shannon 2000:4). In Tomorrow's Table: Organic Farming, Genetics, and the Future of Food, Pamela Ronald and Raoul Adamchak indicate that genetic engineering (GE) is not a farming method, as plant breeding allows only for the transfer of genes between species that are closely related and mixes great sets of genes of unknown function. With genetic engineering, genes can be introduced from any other species, even animals, and usually only one or a few well-characterised genes are brought in at a time (2008:x).

One type of genetic engineering widely used in agriculture and considered by most countries to be an extension of conventional plant breeding is marker-assisted breeding. In marker-assisted breeding, researchers identify the genetic 'fingerprint' of genes that they would like to transfer from one variety to another. They then cross-pollinate the two varieties and create many offspring and identify which of the offspring possess the desired genetic fingerprint. The process is then repeated only with the offspring that has the required fingerprint (Ronald \& Adamchak 2008:10).

In Genetically Modified Foods and Social Concerns Behrokh Maghari and Ali Ardekani pronounce that there are more than 148 million hectares of farmland at present that are utilised for the cultivation of GMO crops worldwide (2011:109). The GMO food that is grown most commonly is crops that have been manipulated to endure spraying by herbicides and crops that yield substances which are lethal to insects. So far, the most important aim of genetically altering food has been to benefit the 'farmers' bottom line' by augmenting harvests, making plants more resistant to pests and ailments, and diminishing the utilisation of herbicides (McLean 2005).

Increasing yields is an especially important aspect, given that there are thousands of people who do not have enough food. ${ }^{3}$ The United Nations Food and Agriculture Organisation document The State of Food Insecurity in the World 2014 states that $14.5 \%$ of people in developing regions are undernourished. In Africa, this figure is $20.5 \%$ and in Sub-Saharan Africa, it rises to $23.8 \%$, the highest percentage in the world (World Hunger

Norman Wirzba indicates, however, that despite arguments that the genetic development of seed to increase yields are the best hope to produce more food, the "vast majority of genetically modified seed grown today is not to increase yield but to withstand herbicide use" (2011:73). 
Organisation 2015). Contrary to popular belief, there is not a food shortage worldwide and the world does in fact produce enough food for everyone (World Hunger Organisation 2015). Food contestation does therefore not mean that the contest is for a limited resource, but rather concerns the distribution of this resource.

It would appear that the argument that GMOs are needed in order to produce enough food to feed the growing world population is, at least at present, not necessarily merited. What then are the ethical issues that this form of biotechnology brings to the table?

In discussing the ethical challenges that GMO foods raise in four categories, McLean indicates that possible risks are seen to the environment and wildlife, to human health, to the socio-economic sphere, and to public trust (2005). In this contribution, I am especially interested in the third aspect, the ethical challenges raised by GMOs within the present day economic powers. It may, however, be helpful to mention very briefly the other possible ethical implications as well.

Ronald and Adamchak discuss the risks associated with eating GMOs, but argue that we are worried about consuming the wrong hazards, pointing out that unlike fluoride for example, genetically engineered traits are composed of the same building blocks as other foodstuff and within one hour, "98\% of the DNA in food is digested completely ... most proteins are digested even faster" (2008:87). Nearly everything we eat has in some way been genetically altered, and nearly every type of food poses some kind of risk (Ronald \& Adamchak 2008:87). Some conventional methods, such as mutation breeding, actually pose even greater risks than GMOs. Mutation breeding is where the seeds are placed in a highly carcinogenic solution to encourage DNA changes, and "surviving seedlings that have new and useful traits" are then adopted by breeders (2008:88). Food that has gone through such a process of mutation, however, can still be certified organic (2008:91). Ronald and Adamchak also further emphasise that no genetically engineered food on the market has to date caused new known allergic reactions in human beings (2008:93).

Potential risks to the environment and wildlife include the fear that the altered genetic material may find their way into other organisms or other members of the species, that modified crops would start competing or breeding with unaltered plants, which would pose a threat to biodiversity, that crops which are monogenetic may not respond suitably to stresses from the environment, and the possible risks posed to non-target species that consume or come into contact with plants that have been genetically altered, such as birds or insects (McLean 2005). A further ethical issue is whether we would be able to leave behind a cleaner environment and abundant and nutritious crops for subsequent generations. Ronald and Adamchak refer to one well-known example of rice (so-called 'Golden Rice') that was genetically altered to contain high levels of Vitamin A by the World Health Organisation, especially for young children and pregnant women in Africa and Southeast Asia that suffer from a Vitamin A deficit, often leading to blindness or even death (2008:94-95). Because of the suspicion with which GMOs are viewed, however, the 'Golden Rice' met with distrust by the media and the public alike.

In theological ethical terms, and borrowing from Ernst Conradie and Newton Cloete's contemporary manifestations of ecological sin in Penultimate perspective on the root causes of environmental destruction in Africa, the concern expressed is related to sin as anthropocentrism and sin as alienation from the earth (2014), or, making use of the classical categories referred to earlier, the sin of human pride.

The greatest extinction threat to birds worldwide is farming, and its unfavourable effects on biodiversity seem set to increase, especially in developing countries (Ronald \& Adamchak 2008:107). 
Considering the costs and limits of industrial agriculture indicates the naivete of the hope many people have that there will always be affordable or even cheap food available. "It is not a solution", Wirzba argues, "to expect farmers, many of them already poor, to become dependent on patented seeds and expensive fossil fuel-derived inputs. It is not a solution to increase yields at the cost of an overall decrease in soil fertility, fresh water availability, and species diversity" (2011:73). Wirzba also mentions that there is considerable pressure on developing countries, such as in Africa, to accept GMO seed for crops such as wheat, but that the usage of this seed will, through the contamination of fields and compromising of traditional varieties, serve to "make African farmers dependent of multinational corporations that hold the patents to the seed and control the fertilizer and herbicide inputs that make the seed grow" (2011:22). International trade agreements, as well as foreign aid, largely determine what food will be grown and consumed in most of the world (Wirzba 2011:22).

The utilisation of GM seed worldwide means that the world's food supply is increasingly being consolidated "in the hands of a small number of very large companies" (Wirzba 2011:73) and international trade agreements tap assets and resources from the global South to countries in the North, "leaving the world's poor impoverished and unable to feed themselves" (Wirzba 2011:74).

I wish to argue that the reflection on the socio-economical impact of GMO food is the most valuable contribution that the field of theological ethics can make to the ongoing debate surrounding the development, production, trade and consumption of genetically altered food.

This notion will be examined further in the following section, specifically in relation to the Christian doctrine of sin, particularly sin as collective.

\section{Genetically Modified Organisms (GMOs) and a Christian Doctrine of Sin}

In Bound to Sin: Abuse, Holocaust and the Christian Doctrine of Sin, Alistair McFadyen discusses some of the reasons why sin has fallen out of use in everyday language, such as secularisation, and the suspicion that the Christian notion of sin is counter-moral or counter-scientific, sin also uses the language of blame and condemnation (2000:3). Stanley Hauerwas also indicates that the very word 'sin' sounds judgemental in Sinsick (2000:7). One possible response would be to limit talk of sin to the religious and private sphere (McFadyen 2000:5).

Wirzba refers to the statement made by Herbert McCabe; "[t]he root of all sin is fear: the very deep fear that we are nothing; the compulsion, therefore, to make something of ourselves; to construct a self-flattering image of ourselves we can worship, to believe in ourselves" (2011:78). For many people, Wirzba continues, this creaturely finite world "is too hard to bear" (2011:79). It is this turning away from God and the creation that God has made, twisting God's life-giving power to serve our own fear, purposes and vanity, we deny ourselves and the rest of creation the ability to be and to flourish, turning our world and even our own bodies in exile (Wirzba 2011:78). Sin, Wirzba argues, "isolates individuals and destroys the fellowship of life together" (2011:114). From this perspective, sin is therefore more than simply an individual's acts of transgression or wrongdoing, or the violation of a moral code. In speaking of sin, also in conversation with biotechnology and GMOs, one could also speak of collective sin.

Collective sin is a notion that is also particularly emphasised in liberation theology. "In the liberation approach," Gustavo Gutierréz indicates, "sin is not considered as an individual, private, or merely internal reality... Sin is regarded as a social, historical fact ... 
considered in this way, the collective dimensions of sin are rediscovered" (1973:175, in Smith 1991:35). This understanding of sin enables liberation theologians to speak of 'social sinfulness', 'institutionalised violence', and 'structural sin' (1983:147, in Smith 1991:35).

South African liberation theologians also made use of the notion of collective sin in opposing the Apartheid regime. The Kairos document, ${ }^{4}$ for example, refers to the sin of oppression as tyranny, the autocratic misuse of power, while the Belhar Confession ${ }^{5}$ speaks of the need for the church to witness against the powerful and the privileged that control and harm others through the seeking of their own interest.

\section{Sin as Collective: Agricultural and other Structures of Power}

In The Nature and the Destiny of Man Reinhold Niebuhr asserts that sin is the result of human beings' anxiety over our own finitude and dependence (1996:168) and states that it is for this reason that unbelief has frequently been emphasised in Christian orthodoxy as the root of $\sin$, or the sin which precedes pride. It is not anxiety itself that is the sin, but what this anxiety gives way to (1996:183). Anxiety is then described to be both the source of human creativity and the temptation to sin. Human attempts to fight their own finitude will always be destructive and bring about pride and sensuality (Niebuhr 1996:185-186).

However, Niebuhr also stresses in Moral Man and Immoral Society that any form of social co-operation requires some form of coercion, which is frequently covert; different philosophies and attitudes will always exist regarding social and political matters, and goodwill and intelligence will only resolve it so far (1947:3-4). The "democratic method of resolving social conflict which some romanticists hail as a triumph of the ethical over the coercive factor, is really much more coercive than at first seems apparent" (Niebuhr 1947:4). The majority, Niebuhr indicates, has its way because of its power, not because it is right (1947:4). The notion of power is also closely linked to sin; power, he continues, is that poison that "blinds the eyes of moral insight and lames the will of moral purpose" (Niebuhr 1947:6).

The possible destructive socio-economic effects are another aspect that challenges GMO foods from an ethical perspective. This may also be expressed as the notion of collective sin mentioned above and is, in my opinion, the aspect where theological ethics may make the most valuable contribution to the ethical discussion on GMOs.

There are fears that the market could be dominated by a few powerful seed companies, which would have a damaging impact on small-scale farmers and traditional practices such as collecting, storing and replanting seed. As a result of biotechnology's proprietary nature,

4 "The KAIROS document is a Christian, biblical and theological comment on the political crisis in South Africa today [1985 - MK]. It is an attempt by concerned Christians in South Africa to reflect on the situation of death in our country. It is a critique of the current theological models that determine the type of activities the Church engages in to try to resolve the problems of the country. It is an attempt to develop, out of this perplexing situation, an alternative biblical and theological model that will in turn lead to forms of activity that will make a real difference to the future of our country" (Preface: The Kairos Document).

5 "The Belhar Confession has its roots in the struggle against apartheid in Southern Africa. This 'outcry of faith' and "call for faithfulness and repentance" was first drafted in 1982 by the Dutch Reformed Mission Church (DRMC) under the leadership of Allan Boesak. The DRMC took the lead in declaring that apartheid constituted a status confessionis in which the truth of the gospel was at stake. The Dutch Reformed Mission Church formally adopted the Belhar Confession in 1986. It is now one of the 'standards of unity' of the new Uniting Reformed Church of Southern Africa (URCSA). Belhar's theological confrontation of the sin of racism has made possible reconciliation among Reformed churches in Southern Africa and has aided the process of reconciliation within the nation of South Africa" (Prologue: The Belhar Confession). 
others are also concerned that basic research may be slowed down and patent protection might delay or even obstruct GMO foods and biotechnology in developing countries (McLean 2005). In Conradie's manifestations of ecological sin, what is at stake in this ethical challenge is sin as consumerist greed, which can be resolved through the virtues of moderation and satisfaction (2014).

In Theology and Biotechnology: Implications for a New Science, Celia DeaneDrummond refers to the power wielded by biotechnology in agricultural practice as "becoming a means of oppressing Third World economies and [it] seems to drive a wedge between rich and poor nations". As a result, the long term social consequences have to be taken into consideration (1997:82). "At the heart of concupiscence," says Ted Peters in Sin: Radical Evil in Soul and Society, "is the denial of our own limits expressed through the consumption of someone else's life-giving power. Those of us who profit from today's First World economies are like vampires, thriving on the blood of unseen victims" (1994:134).

For this reason, Wirzba argues that the genetic modification and patenting of food and seed need to happen in an environment that is shaped by an understanding of the world as a gift. The world as a gift glorifies God and promotes life. This does not indicate the end of genetic research, but rather, appropriate research "will respect the integrity of creatureliness and honour the divine logos (the principles of life and intelligibility) in things. Research that serves the narrow purposes of profitability and power (the glorification of a corporation) rather than the nurture and health of the world, is a desecration" (Wirzba 2011:204).

Economic power, Niebuhr states, argues that a laissez faire approach best serves the general welfare, while at other times it relies on the suppression of freedom, claiming that "peace is more precious" than liberty (1947:33). Where there is unequal power, also in the economic sphere, those who hold power will strive to maintain that by any means necessary (Niebuhr 1947:34). Inequalities of privilege are also inequalities of power (Niebuhr 1947:114).

In Democratising Biblical Studies, Elizabeth Schüssler Fiorenza indicates that a "critical emancipator pedagogy and ethos" criticises the dehumanising power of oppression, but also includes the possibility of the transformation of humanity of both the oppressed and the oppressor, who are both damaged and deformed by domination (2009:10). In a radical democratic system, the manner in which power is exercised is not 'power over' or violence and subordination, "but through the human capacities for respect, responsibility, selfdetermination, and self-esteem" (Schüssler Fiorenza 2009:16). This relates to equal justice, freedom, and dignity for all.

Through the logic of 'natural differences', historical socio-political kyriarchal practices have argued that these differences result in a logical distinction between different groups, such as men and women, slaves and free citizens, etc. (Schüssler Fiorenza 2009:16). Power, Schüssler Fiorenza continues to point out, can be understood either as in a kyriocentric manner as having control and power over others, or in "radical democratic terms as energy that moves us and invigorates life" (2009:150). Other feminist scholars have also highlighted the issue of the misuse of power. Rosemary Radford Ruether, for example, in Sexism and God-Talk, indicates that to the prophetic-liberating tradition of Scripture, there are important themes such as God's defence and exculpating of the oppressed, criticism against systems of power that dominate and the power holders in such structures, as well as the vision of a new age in which the present injustice and oppression will be installed in history through God's intended reign. Especially, she continues, a "denunciation of 
oppressive economic and political power is found in many places in the Prophets" (1983:20). This critique of power relations can also be seen to be central to Jesus' ministry and interpretation of the prophetic-messianic tradition (Radford Ruether 1986:26).

Although Isabel Phiri and Sarojini Nadar argue that African women theologians should not be grouped with feminist theologians, given that feminism seems to be "largely Western, white, and middle-class" to African women (2006:4), the notion of sin as communal and beyond only personal sinfulness also finds expression in the work of African theologian Mercy Oduyoye who, however, refers to the collective evil taking form in "racism and other kinds of exploitation" (1986:244). Although she does not articulate it in this way, it also closely mirrors Schüssler Fiorenza's understanding of 'power over'.

Oduyoye does not interpret the liberation of the exodus events only as a personal redemption from sin, but states that this understanding ignores the "cry of the oppressed" (2002:4). Structures and systems can also be called sinful and evil, such as colonialism and any system that oppresses (2002:4-5). Regardless of Phiri and Nadar's assertion earlier, Oduyoye also indicates that women's theology in Africa is, amongst other features, theology concerned with sexism and patriarchal mistreatment, and exploitation that women suffer (2002:69-73) and seeks to be liberating. It deals therefore deeply with the notion of sin as power exercised 'over' others, an aspect which could also be highly beneficial for the discussion of sin as the misuse of power in relation to GMOs.

\section{Conclusion: Collective Sin as Power and the Eucharist}

In traditional thought, the origin of sin can be traced back to the first human beings eating forbidden fruit, while the cosmic telos in Scripture is described as a feast on the new earth; there is a strong relationship between thinking about sin and about food in the theological tradition ${ }^{6}$. Just as food and eating can be thought of communally, as indicated previously, sin can also be spoken of as more than simply individual wrongdoings and overstepping of moral boundaries, but also as collective and communal sin.

An understanding of sin as collective, a mutual situation that we all share and that not only refers to individuals transgressions, but also the very structures and systems that make up our world is particularly helpful in discussing GMO food through the lenses of a doctrine of sin. This notion also underlines the socio-economic dangers, where large corporations hold a virtual monopoly over the production and selling of GMO food, understanding power as 'power over' and domination. Such an understanding of power can also be dangerous to the environment, as Conradie's manifestations of ecological sin also emphasise, with anthropocentrism and alienation from the earth underlining humanity's 'power over' and supremacy over the earth and consumerist greed being exalted.

To conclude this contribution, I wish to argue that the converse of collective sin can be said to be the Eucharistic community. Like collective sin, this is a community made up of individuals, but one which is also greater than the individuals that form part of it.

6 In the Old Testament a variety of meanings are attached to the themes of food and eating. It can refer to sustenance of the life force, with YHWH being consistently portrayed as "the One providing food for life" (Venter 2011). This theme is also used symbolically and metaphorically to refer to "security and health: taboos ... linked to identity; meals are occasions for establishing communion and extending hospitality; religious feasts, just as the Passover, became important events of celebration, memory and hope" (Venter 2011). In the New Testament food and eating are also stressed. Other than rich imagery or metaphors used for food and the act of eating, other themes that also bear mentioning are Jesus' table-fellowship, the Eucharist, as well as the polemical struggles over food regulations in the emerging inclusive Pauline communities. 
Power as 'power over' is also reversed in the Eucharistic community. It is exactly with the downtrodden, those who had been thrust out of society, Jürgen Moltmann states, that Jesus celebrated 'the messianic feast' (1992:258). Joy McDougall indicates that it is this 'open friendship', the "reciprocal dynamic of affection and respect, self-giving and selfdistinction", that is, for Moltmann, the self-giving love of Jesus Christ made visible (2005:142-143). Within this paradigm of open friendship, both God's fellowship with humanity and the fellowship of human beings with one another takes form (McDougall 2005:143). Nowhere is this community and fellowship better exemplified than in the messianic feast of the Eucharist.

Michael Northcott argues that Jesus Christ's "association of the Kingdom of God with the messianic banquet", recalled the "egalitarian moral economy of the ancient Israelites" and that through their participation in table fellowship, those who are "outside the orbit of grace are invited in" (2008). The Eucharistic meal can therefore be said to stand against the conception of power as domination and 'power over'.

An understanding of eating shaped by the Eucharist, Wirzba further indicates, is one that "will also potentially lead eaters into an understanding of food as ultimately rooted in the grace of God" (2011:29). Such an understanding also makes anthropocentrism impossible; just as food is rooted in the grace of God, the Eucharistic meal also reminds believers that our very being and existence is dependent on God's grace. This is also profoundly evident in Rowan Williams' striking observation: "We do not work our salvation in offering the Eucharistic oblation; we witness to the share we have been given in the glorified life of Christ, manifest in the rest of our lives as charity, humility, and pity. And the purity of our offering depends upon our commitment to the Christ through whom it is offered" (1982:11).

It is highly unlikely that Christian theological critique of GM food would be able to bring to an end the utilisation of this form of biotechnology. From a theological ethical perspective, what we can do is to offer certain guidelines to guard against in its implementtation. Sin as the abuse and misuse of power, also collective speaking in the structures which make up the agricultural systems of food production and distribution clearly influences the manner in which we will view and discuss GMOs and biotechnology. In this contribution, I have argued that the communal Eucharistic community can act as a countermeasure to the understanding of power as domination and 'power over', to anthropocentrism, alienation from the earth, and greed. The Eucharistic community stresses commensality and fellowship, also with the poor, the marginalised and the oppressed, selfgiving and the open friendship and love of God for all humankind. 


\section{REFERENCES}

Brown, D 2008. "Symbol, Community and Vegetarianism”, in R Muers \& D Grumett (eds.) Eating and Believing: Interdisciplinary Perspectives on Vegetarianism and Theology. London: T\&T Clark (e-book).

Chapman, AR 1999. Unprecedented Choices: Religious Ethics at the Frontiers of Genetic Science. Minneapolis: Fortress Press.

Conradie, EM 2014, Penultimate Perspective on the Root Causes of Environmental Destruction in Africa. Keynote paper presented at 6th Conference of the African Association for the Study of Religions on "Religion, Ecology and the Environment in Africa and the African Diaspora", held in Cape Town, 30 July-2 August 2014.

Dean-Drummond, C 1997. Theology and Biotechnology: Implications for a New Science.

London: Geoffrey Chapman.

Hauerwas, S 2000. "Sinsick," in CE Braaten \& RW Jenson (eds.) Sin, Death and the Devil. Grand Rapids: Eerdmans. pp. 7-21

Louw, DJ 2008. Cura Vitae: Illness and the Healing of Life. Wellington: Lux Verbi. Maghari, BM \& Ardekani, AM 2011. Genetically Modified Foods and Social Concerns. Avicenna Journal of Medical Biotechnology, Jul 3(3):109-117.

McDougall, JA 2005. Pilgrimage of Love: Moltmann on the Trinity and Christian Life. New York: Oxford University Press.

McFadyen, A 2000. Bound to Sin: Abuse, Holocaust and the Christian Doctrine of Sin. Cambridge Studies in Christian Doctrine. Cambridge: Cambridge University Press.

McLean, MR 2005. The Future of Food: An Introduction to the Ethical Issues in Genetically Modified Foods. Paper delivered at a conference on The Future of Food: Legal and Ethical Challenges, held at Santa Clara University on 15 April 2005.

Moltmann, J 1992. The Spirit of Life: A Universal Affirmation. Minneapolis: Fortress Press. Niebuhr, R 1996. The Nature and the Destiny of Man: A Christian Interpretation: Human Nature (first published 1941). Louisville: Westminster John Knox Press.

Niebuhr, R 1947. Moral Man and Immoral Society. Eugene: Wipf \& Stock.

Northcott, MS 2008. "Eucharistic Eating, and Why Many Early Christians Preferred Fish", in R Muers \& D Grumett (eds.) Eating and Believing: Interdisciplinary Perspectives on Vegetarianism and Theology. London: T\&T Clark (e-book).

Oduyoye, MA 2002. Beads and Strands: Reflections of an African Woman on Christianity in Africa. Akropong-Akuapem: Regnum Africa.

Oduyoye, MA 1986. "The Value of African Religious Beliefs and Practices for Christian Theology," in DW Ferm (ed.) Third World Liberation Theologies. Maryknoll: Orbis Books.

Peters, T 1994, Sin: Radical Evil in Soul and Society. Grand Rapids: Eerdmans.

Phiri, IA \& Nadar, S (eds.) 2006. African Women, Religion and Health: Essays in Honor of Mercy Amba Ewudziwa Oduyoye. Maryknoll: Orbis Books.

Radford Ruether, R 1983. Sexism and God-Talk. London: SCM Press.

Schüssler Fiorenza, E 2009. Democratizing Biblical Studies: Towards an Emancipatory Educational Space. Louisville: Westminster John Knox.

Shannon, TA 2000. Made in Whose Image? Genetic Engineering and Christian Ethics.

New York: Humanity Books. 
Smith, C 1991. The Emergence of Liberation Theology: Radical Religion and Social Movement Theory. Chicago: University of Chicago Press.

The Economist, February 2011, The 9 billion-people question: A Special Report on Feeding the World.

Ronald, PC \& Adamchak, RW 2008. Tomorrow's Table: Organic Farming, Genetics, and the Future of Food. Oxford: Oxford University Press.

Venter, R 2011. Towards an Ethics of Food and Eating: The Shape of the Challenge.

Unpublished paper presented at the Theological Society of South Africa, Johannesburg, June 2011.

Williams, R 1982. Eucharistic Sacrifice: The Roots of a Metaphor.

Bramcote: Grove Books.

Wirzba, N 2011. Food and Faith: A Theology of Eating. Cambridge:

Cambridge University Press.

2015 World Hunger and Poverty Facts and Statistics, World Health Education Service.

Available online:

http://www.worldhunger.org/articles/Learn/world\%20hunger\%20facts\%202002.htm

The Belhar Confession.

The Kairos Document. 